FACTA UNIVERSITATIS

Series: Law and Politics Vol. 15, N N $^{\circ}$ 2017, pp. 325 - 334

https://doi.org/10.22190/FULP1704325C

Review Paper

\title{
SECRET MONITORING: A METHOD OF FIGHTING AGAINST TERRORISM
}

UDC 351.759:327.88

\section{Nedeljko Cvetković}

\author{
National Security Academy, Belgrade, Republic of Serbia
}

\begin{abstract}
The danger of terrorism as a social phenomenon is increasingly present and threatens both individual states and the entire international community. The current level of development in the contemporary world allows terrorists to combine the means of modern technology and those of mass destruction, threatening every civilized society. In the suppression of this plague of the modern world, the use of secret surveillance of people is inevitable as a means of covert collection of data and information about subjects who may be involved in possibly dangerous activities. Yet, the use of secret surveillance of people interferes with the basic human rights and civic freedoms and, therefore, requires the existence of adequate legislation which should be fully observed in the activities of the security sector, as well as a high level of professional training of the security operatives engaged in the process of applying these measures. Although the secret surveillance of people involves many measures and procedures, one of the most commonly used measures is secret monitoring and recording. The significance of this measure is best reflected in the amount of collected evidence.
\end{abstract}

Key words: terrorism, secret surveillance of people, special evidence, secret monitoring and recording, secret monitoring and recording tactics.

\section{INTRODUCTION}

Curiosity is in the very nature of any human being. It gives birth to creativity. Without this trait, it is practically impossible to achieve any scientific discovery, create a work of art or make advancement in any area of civilization, be it on personal or collective level. Curiosity that we all experience when discovering something new is one of the strongest human feelings. As opposed to curiosity and discovery, there is fear of the unknown, the fear of something new that can bring about unpredictable dangers and consequences.

Striving to secure his safety and survival, man has constantly been collecting data about everything that surrounds him, evaluating the data and making decisions that

Received October $17^{\text {th }}, 2017 /$ Accepted November $21^{\text {st }}, 2017$

Corresponding author: Nedeljko Cvetković, Master Manager in Terrorism, Organized Crime and Security,

National Security Academy, Belgrade, Republic of Serbia

E-mail: cvele1981@gmail.com 
directly influence not only his immediate survival but also the progress of the society as a whole. In the first human societies, gathering information was entrusted to chosen individuals. In modern states, this activity is conducted in an organized manner by authorized institutions.

Secret surveillance is often the first step in gathering information. The term surveillance frequently has a negative connotation. It calls to mind images of secret investigations and spy movies. Surveillance seems to be directly associated with observation, where one person watches over another in order to uncover suspicious and ambivalent behaviour. Then, there are surveillance cameras. Whether used for public safety or for securing private property, they can record deviant behaviour, ranging from unwanted activities to criminal offences. However, surveillance can also refer to direct tapping of phone lines. These forms of surveillance require the application of modern technologies, such as video surveillance systems, control of Internet communications, phone tapping, etc.

Taking into account the possibilities brought by modern technologies, the area of supervision has significantly improved in recent years. Information obtained through secret surveillance can be used as evidence and, in the context of the global fear of terrorism, even casual comments related to acts of violence can be taken into account.

Etymologically, the roots of the word surveillance may be found in the French word "surveiller", which literally means "to watch over". Surveillance can be defined as a series of procedures where special attention is given to certain individuals or groups whose behaviour goes beyond the boundaries of curiosity (Lyon, 2007:13). The importance of surveillance can be determined within the coordinates that "anyone who can pinpoint the time and place of some event or activity already has the situation under control" (Lyon, 2007: 16).

In his study of surveillance, Professor David Lyon of Harvard University concludes that surveillance is "the focused, systematically and routine attention to personal details for purposes of influence, management, protection or direction"(Lyon, 2007:14). By defining surveillance in this manner, Lyon points out to four aspects that broaden our understanding of secret surveillance and its goals. First, surveillance is focused on gathering information about individuals and groups. Second, it must be systematic and intentional "rather than random and arbitrary". Third, it is routine because it is part of the ordinary administrative apparatus, which is characteristic of all modern societies. Fourth, it has a wide range of purposes, leading to "subtle forms of influence or control" (Richard, Neil, 2013: 1937).

The legal basis, importance and timeframe of applying surveillance are issues that are, as a rule, discussed after successful terrorist acts and failure of the security sector.

\section{SECRET MONITORING AND RECORDING}

Current level of technological development has brought a revolution into our way of living. Range and diversity of surveillance available today are unprecedented in human history. Increased number of subjects involved follows this trend. This tendency became apparent after the terrorist attacks on $11^{\text {th }}$ September 2001, all in the name of fighting terrorism. "Special measures for secretly collecting data are those used in a concealed way by government agencies, mostly those tasked with security, and the use of which encroaches upon the civil rights of an individual" (Đokić, 2014:5). 
"Taking into consideration that in fighting terrorism such special measures, especially the ones related to secret monitoring and recording, are conditio sine qua non, we can safely say that their use will continue to prove necessary in preventing acts of terrorism and other criminal acts" (Lečić, 2014:98).

We can point out that secrecy in collecting data is a fundamental trait of these special measures, regardless of their legal basis (Đokić, 2014:2). Special measures of covert gathering of information can additionally be defined as "a way of collecting data that enables us to do so without the knowledge of individuals or groups that are being investigated" (Petrović, Drakulić, 2015: 11). According to the current Criminal Procedure Code of the Republic of Serbia, special evidence-gathering actions are:

- secret surveillance of communication (Articles 166-170),

- secret monitoring and recording (Articles 171-173),

- simulated activities (Articles 174-177),

- computerised research of data (Articles 178-180),

- controlled delivery (Articles 181-182),

- undercover investigation (Articles 183-187).

"These measures are as a rule taken before the beginning of criminal proceedings, with the goal of discovering structure, form, extent and methods of operation of criminal organizations in order to legally prosecute their members, and their results can be used as evidence in court" (Bugarski, 2014:24).

Among these measures, a special place belongs to secret monitoring and recording as one of the most controversial of the special evidence-gathering actions. By using this measure against terrorist and organized criminal groups, more than $50 \%$ of total evidence material is collected. The foundation of this measure is direct observation, performed either by following a suspect or by monitoring locations, in order to obtain facts that are meaningful to the prosecution authorities (Krivokapić, Žarković, Simonović, 2003: 183).

Secret monitoring has followed the development of human society. Records on secret monitoring can be found in the oldest of civilizations, either in the form of reconnaissance or stalking one's enemies. "Chinese military philosophers pointed out the importance of the information supplied by the vanguards or scouts as far back as $6^{\text {th }}$ century BCE, thinking that knowledge is one of the most important conditions in winning both militarily and politically" (Herhnan, 1989:1-12).

"Even in the Bible it is stated that Israelites were using intelligence agents in order to gain information as well as material wealth, and Moses sent them to inquire of the land of Canaan, saying to them, "Go this way and climb up to the mountain, and see the land and the people who have settled in it, whether they are strong or weak, whether they are few or many" (Herhnan, 1989:1-12)

In Serbia, this special evidence-gathering action is conducted by the Police, the Security Intelligence Agency (BIA) and the Military Security Agency (VBA). The institution vested with this authority is obliged to make daily reports, which are then delivered to pre-trial judge and district attorney (upon his/her request) along with the related recordings.

\section{Purpose OF SECRET MONITORING}

Secret monitoring is used to obtain basic information about an object (a monitored person) if no informant network or other data sources are available. 
"The purpose of defining this special evidence action is the detection of contacts and communication of the suspect in public places and places where access is restricted or in the premises (which may include the means of transport of other persons if the suspect is likely to be present or use these means of transport)" (Bugarski, 2014:57). Other purposes are:

- "Determining the links and contacts of the suspect with other persons,

- determining accomplices of the suspect,

- spotting the exchange of the object of the criminal act,

- locating the wanted person,

- discovering the hideouts of the suspect,

- determining elements of personal life of the suspect, such as habits, vices, life problems, how much money the suspect spends, etc.

- confirming the information already collected about a subject,

- testing informants, etc." (Popara, 2006:307)

High flexibility in the application of this measure allows combination with other operational and technical measures and actions, their sublimated application being a significant tool in the fight against all forms of crime.

Secret monitoring and recording are conducted by specialized teams whose members should be specially trained for this type of operative work. In some situations, the entire operation is dependent on the training of the security operative agents. Members of this department should have a high degree of self-confidence, expressed self-initiative (reflected in motivation and activity), patience, discipline, ability to observe details, collective spirit and other qualities. Members of these teams often work long hours and may be engaged all day long, which requires good physical and mental preparation.

"Ideal qualities for a member of secret monitoring and recording team are:

1. Common appearance: an agent should be neither too fat nor too skinny, neither too tall nor too short, and without distinctive facial features (beard, moustache, scars, etc);

2. Good dress sense: clothes should not be too elegant, without graphic motifs and police badges; agents should wear no jewellery, nor use strong perfumes and colognes;

3. Ability to look inconspicuous and to get rid of the "policeman" look;

4. Being Mr. Noboby and Mr. Anyone, i.e. look like Mr. Average" (Pipović, 2013:63).

In performing the tasks from their field of expertise, specialized secret monitoring and recording teams use a diverse range of resources. Modern security problems impose the need to use different means of transport (vehicles, motorcycles, and bicycles), different means of communication, documenting and monitoring devices, camouflage devices, disposal of operational funds, etc.

\section{Preparation of Secret Monitoring}

In order to make the most efficient and adequate use of secret monitoring and recording, it is essential to take preparatory actions in as much detail as possible. The preparation proceedings include: briefing all team members on the available data about "the object"/suspect under observation, determining team leaders, specifying the role each individual on the team, anticipating the possible developments of the situation in order to preclude the negative scenario, etc. Preparation also entails defining the tasks for each individual on the team, defining their roles and responsibilities within the team. The 
ultimate number of team members necessary to complete the assigned task depends on the complexity of the secret monitoring task.

Adequate preparation also requires getting to know the suspect, which can be done by using photos, videos or direct observation. Recognizing the face from the photos can be difficult at times, depending on the age and quality of the photo. It is also vital to introduce team members with all other data that may facilitate the successful completion of the assigned task (Popara, 2008:163). Direct observation is the best way to introduce team members to the suspect. It brings the possibility of a mistake down to the minimum. All the essential information on the person under observation should be provided by the agent working on the specific case (Popara, 2008:164).

\section{METHOdS OF SECRET MONITORING}

In his book "Criminalist tactics I", Vladimir Krivokapić points out to two methods of secret monitoring: following the suspect on foot and using vehicles (Krivokapić, 2000:376).

\subsection{Secret monitoring on foot}

Secret monitoring on foot is the basic technique used by the members of the department that conducts this measure. It is done by tailing and closely monitoring the suspect from a safe distance in order to detect and note the suspect's contacts, actions, interests, etc. (Popara, 2008:165). When applying this measure, it is first necessary to walk closer to the suspect for a short period of time in order to confirm his identity and the facts introduced to the members of the team during preparation. Definitive confirmation of physical appearance (height, stance, manner of walking, dressing, etc.) is required (Popara, 2008:165).

During the application of this type of secret monitoring, there are several types of formations used by team members. One of them is the ABC method (Palmiotto, 1998:142). In this method of secret monitoring on foot, three members of the team take turns in following the suspect. One agent walks directly behind the suspect; another agent walks behind the first one and observes both the suspect and the agent in front of him, while the third member of the monitoring team walks across the street, parallel to the suspect, and monitors the surroundings, thus ensuring the secrecy of the task. Occasionally, team members will switch places in order to ensure the quality of their work and protect the secrecy of the measure.

The parallel type of secret monitoring on foot means that team members walk across the street, parallel to the suspect. The positive side of this tactics is the fact that the object/suspect can hardly detect it, no matter how many times he turns around or makes sudden movements intended to reveal the members of the monitoring team.

Relay system is the type of secret monitoring tactics that can be applied only in certain situations. It is usually combined with the secret surveillance of communications. This type of monitoring requires the knowledge of the route used by the object/suspect. Team members are dispatched along this route and tasked to note that the object/suspect has reached that point on the route and to inform the next team member about it. In order to perform the assigned task properly, a large number of agents is needed for this type of secret monitoring.

Secret monitoring can also be performed in a stationary form. In this case, team members stay in one place (watchtower, lookout), constantly surveying the surroundings and recording every important event (Popara, 2008:166). 
These types of secret monitoring are only some of the methods for conducting this special evidence-gathering action. In practice, these secret monitoring methods are frequently combined in order to ensure the best results in the assigned task. We can safely say that there is no universal way of secret monitoring because the team activities and conduct often depend on the situation, object/suspect under observation, and the location where it all takes place. It is vital to adapt to any situation, and the way agent operate cannot be the same in rural and urban settings, in crowded street with heavy traffic and those with no traffic at all (Popara, 2008:166). The adequate accomplishment of the assigned tasks can be ensured by providing proper training and selection of monitoring team members.

\subsection{Secret monitoring by using vehicles}

This method of secret monitoring is used when the object/suspect uses his own car, public transportation (bus, tram or train) or taxi to get around. Secret monitoring by using a car is much more complex and difficult than secret monitoring on foot because the possibility of being detected by the object/suspect is much greater; moreover, it requires many vehicles and adequate coordination among them. The drivers are usually members of the team skilled in driving, able to react quickly, and familiar with the location where the action takes place. Each driver has to go through proper training and spend some time as a member of the team involved in secret monitoring on foot (Popara, 2008:172).

Vehicles are used as assistance to the team working on foot. They may be used to control the object/suspect's movement, and the team members working on foot can take a break in the vehicles, or change their clothes if needed, etc. The characteristics of vehicles used for secret monitoring are as follows:

- they are of dark and inconspicuous colour;

- they are equipped with at least a $1.600 \mathrm{cc}$ engines;

- they are agile (able to catch up with the suspect's vehicle in a short time);

- they have four doors (enabling the members to get in and out easily);

- their manufacturer and type should be different from the ones commonly used by thelaw enforcement of the given state;

- they should not have any distinctive markings;

- teams can use specialized vehicles, most often vans or other delivery vehicles adapted and equipped with special equipment.

In order to be successful, secret monitoring by using vehicles requires the application of certain tactics. First, in the process of preparing this type of monitoring, it is necessary to acquire information about the type of vehicle used by the object/suspect, details about his potential route and destination. The goal is to remain undetected throughout the process of monitoring the suspect's movement. Should the manner of the suspect's driving (sudden turns, irrational stopping, etc.) at any time hint at detection of the team members, it is necessary to abort the measure. Secret monitoring by using vehicles and the required coordination among the agents are unthinkable without proper radio connection in each vehicle. The movement of the vehicles used for secret monitoring should be adjusted to the given situation, and the vehicle formation depends on the size of the town, street grid, traffic density, etc. (Popara, 2008:172). Thus, in urban areas, the distance from the object/suspect under observation should be smaller, while in rural areas it can be bigger. One of the most important rules in this type of secret monitoring is to avoid situations in which one must overtake the object's vehicle (Popara, 2008:173). 


\section{IDENTIFYING THE OBJECT'S CONTACTS}

During the monitoring of an object/suspect, team members may note that the object is contacting a number of persons who are unknown to them. In such a case, it is necessary to identify these contacts. The identification can be done by description, photographing, detecting their identity via the vehicles used by the contacts, their home address or workplace. These data may also be collected through secret monitoring, either on foot or by using vehicles; but, in this case, there is no preparation involved as it is impossible to foresee when and where the object/suspect will make contact with unknown persons. Thus, acquiring data on the object's contacts is done on the go. Identification of the object's contacts is done only for those who are deemed suspicious and who are unknown (Popara, 2008:174).

The decision on whether a person should be identified is made by each individual agent based on the type of contact that the person has with the object of monitoring. This decision is influenced by the type of contact and the overall circumstances. It is necessary to estimate the time and the place of the contact, manner of communication (covert, open or closed), maneuvers before the contact, and whether those were aimed at evading the monitoring team. It is vital to note whether there was an exchange of suspicious objects (packages, money, documents) and how the exchange was performed (in a transparent or clandestine manner) (Popara, 2008:174). After analyzing these facts, the agent makes a decision on whether identification is needed; only those persons who are deemed suspicious will be identified. During the identification, the suspect's contacts are subject to the same methods as the suspect under observation (Popara, 2008:175).

\section{DOCUMENTING AND REPORTING WHILE MONITORING}

Besides observing and following the suspect, secret monitoring also includes recording and documenting of all relevant facts, both in video and photographic format. Therefore, the use of video equipment is essential in secret monitoring. Photographic and video documenting is an excellent addition to basic monitoring, especially if the measure is used in order to obtain proof of certain activities (contacts made by the suspect, committed criminal acts, exchange between suspects, etc.). Adequate footage is the most trustworthy evidence, so we can say that recording combined with monitoring is the "high risk - high reward" equation (Krivokapić, Krstić, 1999: 355)

In order to successfully record an event if the circumstances allow it (e.g the suspect's contact with another in a familiar location), it is necessary to prepare well (e.g. to observe the mentioned location beforehand). The most common method of recording a contact, or any other important event, is to use a specialized vehicle equipped with photo and video gear and relevant communication devices for coordination with the rest of the monitoring team.

When executing the measure of secret monitoring, agents use different technical means which enable quick and precise location of the object, such as the GPS device or "ANPR" (City Sync's JET Roadrunner) device for automatic recognition of registration plates. These technical devices make the team's job easier and ensure higher efficiency of monitoring (Jenkins, 1988: 337).

After completing the task, members of the monitoring team write a detailed report. It should contain all important facts (actions, contacts, vehicles used, descriptions of important events, etc.) gathered in the course of monitoring. To ensure that nothing goes unnoticed, each team member helps make the most precise report possible. Each report 
comes with an attachment of photos and video material recorded during observation (Popara, 2008:176)

Lack of information in cases dealing with terrorism can be overcome with efficient use of secret monitoring. More than half of total evidence material is collected through this special evidence-gathering action (Popara, 2010:240). However, secret monitoring must be performed in compliance with the applicable law and in full observance of the human and civil rights and liberties guaranteed by national and international documents.

The most effective way of fighting terrorism is prevention. Secret monitoring may be highly useful; given the fact that its first rule is secrecy, it makes may facilitate obtaining timely information in a covert manner. In the end, we can say that secret monitoring performed by teams of skilled professionals can spearhead the war against terrorism, provided that there are adequate legal provisions regulating this matter, proper selection and quality training of security sector professionals, and specialized technical equipment and devices to facilitate these special evidence-gathering activities.

\section{CONCLUSION}

Terrorist activities become more and more complex; the manifestation left to the imagination of their inspirers and organizers necessarily requires constant adjustment and finding new ways and methods in opposing this social phenomenon. The tendency of dynamic changes in the mode of operation, the choice of objectives, the selection of assets and targets of terrorist organizations has imposed the need to adopt new legislation at the national and international level that will improve the work of existing bodies and establish the new ones, primarily within the executive authorities, whose adequate use should enable a more efficient fight against terrorism.

In the process of detecting and neutralizing terrorist activities, security sectors worldwide must try to compensate for the information deficit by using special procedures and measures of secret data collection, such as secret surveillance, which is an indispensable segment in the fight against terrorism. Application of these measures enables the timely detection of terrorist activities, thus cancelling the concealment and secrecy, as the basic features of the activities of terrorist organizations. The use of classified data collection poses a risk of violating fundamental human rights and freedoms, but the importance of secret surveillance is such that countries cannot give up collecting evidence necessary in the process of counteracting contemporary terrorism.

Applying secret surveillance by the security sector implies a partial restriction of basic human rights. This problem inevitably "involves a balance between our values and security. It presents a challenge in finding answers that successfully deal with terrorism, but minimally damage our values" (David, 2002:271). Balance between privacy and security is at the centre of debate in democratic societies. Taking into account the fact that terrorism takes an increasing share in state security threats, it is necessary to increase the powers of the security agencies in order to detect and neutralize terrorist activities.

The legal basis, the importance of supervision and the timeframe in which it can be applied is, as a rule, discussed after the terrorist attacks and failures in the work of security structures. This is best seen in the case of France which, after the terrorist attacks in Paris, has allowed the security sector a number of measures that extend the scope of supervision over citizens. The new law allows the security sector to supervise the digital and mobile 
communications of individuals and groups suspected of terrorism without obtaining the prior approval of the court, as well as to search the houses and objects connected to the suspects, except for the housing facilities of judges, prosecutors and lawyers. As a technical measure, the deactivation of all Internet accounts that promote terrorism and extremism is highlighted.

The expansion of authority, its misunderstanding or malpractice lead to abuse. As a way of overcoming these traps, there is a need to improve the existing systems of controlling the application of classified data control. "The state must control and protect its guardians, to make sure that they act adequately" (Ignjatović, 2016:23).

Secret monitoring is one of the most important and most commonly used operative methods of secret data collection. Classifying secret monitoring in national legislation as part of special evidence actions and accepting information collected in this way as evidence has significantly contributed to the detection, prevention and prosecution of terrorist activists. Modern technical development is a necessary condition for adequate execution of secret monitoring. Bearing in mind that terrorist organizations often use all the benefits of technological development, timely procurement and implementation of modern technical devices is vital for the efficiently collection and use data.

The successful implementation and execution of secret data collection comes from cooperation between the security sector, the judiciary and the prosecution. We can conclude that the application of secret monitoring and recording provides reliable, high-quality and timely data, thus enabling timely reaction of counter-intelligence, intelligence, police, military and judicial authorities. This sequence of events is aimed at neutralizing or destroying terrorist activities, which each country aspires to.

\section{REFERENCES}

Bugarski, T., (2014), Dokazne radnje u krivičnom postupku, Pravni fakultet Univerziteta u Novom Sadu. David, C., (2002.), The New Global Terrorism, "The Four Waves of Rebel Terror and September 11."

Đokić, K. (2014.),Parlamentarni nadzor nad primenom posebnih mera za tajno prikupljanje podataka u Srbiji, Beogradski centar za bezbednosnu politiku.

Đokić, K., (2014.), Parlamenti na specijalnom zadatku: nadzor nad primenom posebnih mera za tajno prikupljanje podataka, Beogradski centar za bezbednosnu politiku.

Ignjatović, D.,(2015.), Mere presretanja komunikacije i zadržavanja podataka iz perspektive Strazbura $i$ propisa i prakse u Republici Srbiji, Beogradski centar za bezbednosnu politiku, Beograd.

Jenkins, P., (1988.), Surveillance Training Tradecraft, the professional s Guide to Surveillance Training, Anti Surveillance - Designs and Patents Act, Harrogate.

Krivokapić, V., (2000.), Kriminalistička taktika I, Policijska akademija, Beograd.

Krivokapić, V., Krstić O., (1999.), Kriminalistička taktika II, Policijska akademija, Beograd.

Krivokapić, V., Žarković, M., i dr.,(2003.), Kriminalistička taktika, VŠUP, Београд, 2003.

Lečić, B. (2014.), Evropski modeli organizacije $i$ nadležnosti službi bezbednosti u suzbijanju terorizma, doktorska disertacija, Univerzitet u Novom Sadu pravni fakultet.

Lyon, D., (2007.), Surveillance Studies: An Overview, Polity Press.

Palmiotto, M. J., Criminal Investigations (fourth edition), CRC Press, Taylor\&Francis Group, New York 2013.

Petrović P., Drakulić Đ., i dr. (2015.), Posebne mere tajnog prikupljanja podataka: vodič za nadzor, Beogradski centar za bezbednosnu politiku.

Pipović, N., (2013.), Metodi tajnog nadzora u suzbijanju organizovanog kriminala, Godišnjak studenata broj 2/2013, Pravni fakultet, Univerzitet u Istočnom Sarajevu.

Popara, V., (2006.), Tajno praćenje- novi aspekti, Bezbednost, br.2/06. MUP R. Србије, Beograd.

Popara, V., (2008.), Taktika tajnog praćenja, bezbednost br. 1-2/2008, Beograd.

Popara, V., (2010.), Specifičnosti postupanja jedinica za opservaciju prilikom realizacije kontrolisane isporuke droge, Bezbednost, Beograd, br. 1/2010.

Richards, Neil M., (2013), The Dangers of Surveillance, Harvard Law Review, Vol.126, No.7 (pp.1934-1965); https://harvardlawreview.org/wp-content/uploads/pdfs/vol126_richards.pdf 


\section{TAJNI MONITORING - METOD BORBE PROTIV TERORIZMA}

Opasnost koju terorizam kao društvena pojava nosi sa sobom je sve prisutnija i ugrožava kako države, tako i čitavu međunarodnu zajednicu. Današnji nivo svetskog razvoja omogućuje teroristima kombinovanje sredstava moderne tehnologije $i$ sredstava za masovno uništenje, čime prete svakom civilizovanom društvu. U suzbijanju ove pošasti savremenoga sveta nezaobilazno mesto zauzima tajni nadzor lica, kojim se na prikriven način prikupljaju podaci i informacije o nosiocima ugrožavajuće delatnosti. Upotrebom tajnog nadzora lica vrši se zadiranje u osnovna ljudska prava i slobode građana, što iziskuje postojanje adekvatne zakonske regulative, postupanje bezbednosnog sektora u skladu sa istim, kao i visok stepen stručne i profesinalne obučenosti pripadnika koji su angažovani u postupku primene ovih mera. U korpusu mera i postupaka koje obuhvata tajni nadzor lica, izdvaja se tajno praćenje $i$ snimanje, kao jedna od najčešće primenjivanih mera. Značaj ove mere najbolje se ogleda $u$ količini dokaznog materijala koji se prikupi primenom ove mere.

Ključne reči: terorizam, tajni nadzor lica, posebne dokazne radnnje, tajno praćenje i snimanje, taktika tajnog praćenja i snimanja. 